\title{
Apokatopinen maailmanmaisema: Paratiisin ikonografia ja satelliittiperspektiivi Petri Ala- Maunuksen 2000-luvun öljyvårimaalauksissa
}

Hilja Roivainen

\section{Korkealta vuorelta avautuva maail- manmaisema}

Tavoitteeni on analysoida artikkelissa Petri Ala-Maunuksen (s.1970) maisemamaalauksia utooppisen paratiisimaiseman määritelmän avulla. Kytken Ala-Maunuksen maalaukset La-la Land (2012) ja Übernatur (2012) utooppisen maisemamaalauksen jatkumoon, johon $\mathrm{mm}$. niin sanotut maailmanmaisemat kuuluvat. Vertaan Ala-Maunuksen maalauksia maailmanmaiseman lajia (Weltlandschaft) edustavaan Joachim Patinirin (1480-1524) maalaukseen Kharon ylittämässä Styks-jokea (n. 1520-1524). ${ }^{1}$ Tarkastelen erityisesti maailmanmaiseman toposta sen aatehistoriallisessa, utooppisia maisemavisioita sisältävän kolonialismin kontekstissa sekä yhteydessä maantieteilijä Denis Cosgroven määrittämään globaalin maiseman käsitteeseen. ${ }^{2}$

Alankomaiden kauppapääkaupungissa Antwerpenissä työskennelleen, syntyperäisen flaamilaisen Joachim Patinirin maalaus Kharon ylittämässä Styks-jokea on hyvä esimerkki maailmanmaisemasta. Patinirin maalaus käsittää 1500-luvun maailmanmaisemalle tyypillisen, katsojan edessä aukeavan laajan näkymän harmonisesta universumista sekä korkean horisontin ${ }^{3}$, jota kohden katsojan katse ohjataan. Lintuperspektiivin, korkean horisontin ja illusorisen esitystavan ${ }^{4}$ käyttäminen yhdistää Petri Ala-Maunuksen maalaukset Patinirin maalauksessa tunnistettavaan maailmanmaisemaan.

Cosgrove lukee Patinirin yhdessä Lucas Cranachin ja Albrecht Altdorferin kanssa maailmanmaiseman ensimmäisiin kuvaajiin 1500-luvun alun maisemamaalaustaiteessa. Cosgrove tulkitsee 1500-luvun alankomaalaisessa maalaustaiteessa kehittyneen maailmanmaiseman kuvatyypin ilmentävän Erasmuksen ajatusta kosmografiasta. Cosgroven mukaan ajan kosmografinen käsitystapa auttoi 1500-luvun alun eurooppalaisessa maalaustaiteessa hahmottamaan imperialismin seurauksena muuttuvaa maailmankuvaa. Maalaus yhdistää universumin mantereet ja taivaat yhdeksi kartaksi. Kosmografiat sisältävät usein myös kuvauksen maailman jatkuvasta tuhoutumisesta ja uudelleen syntymisestä. ${ }^{5}$ 


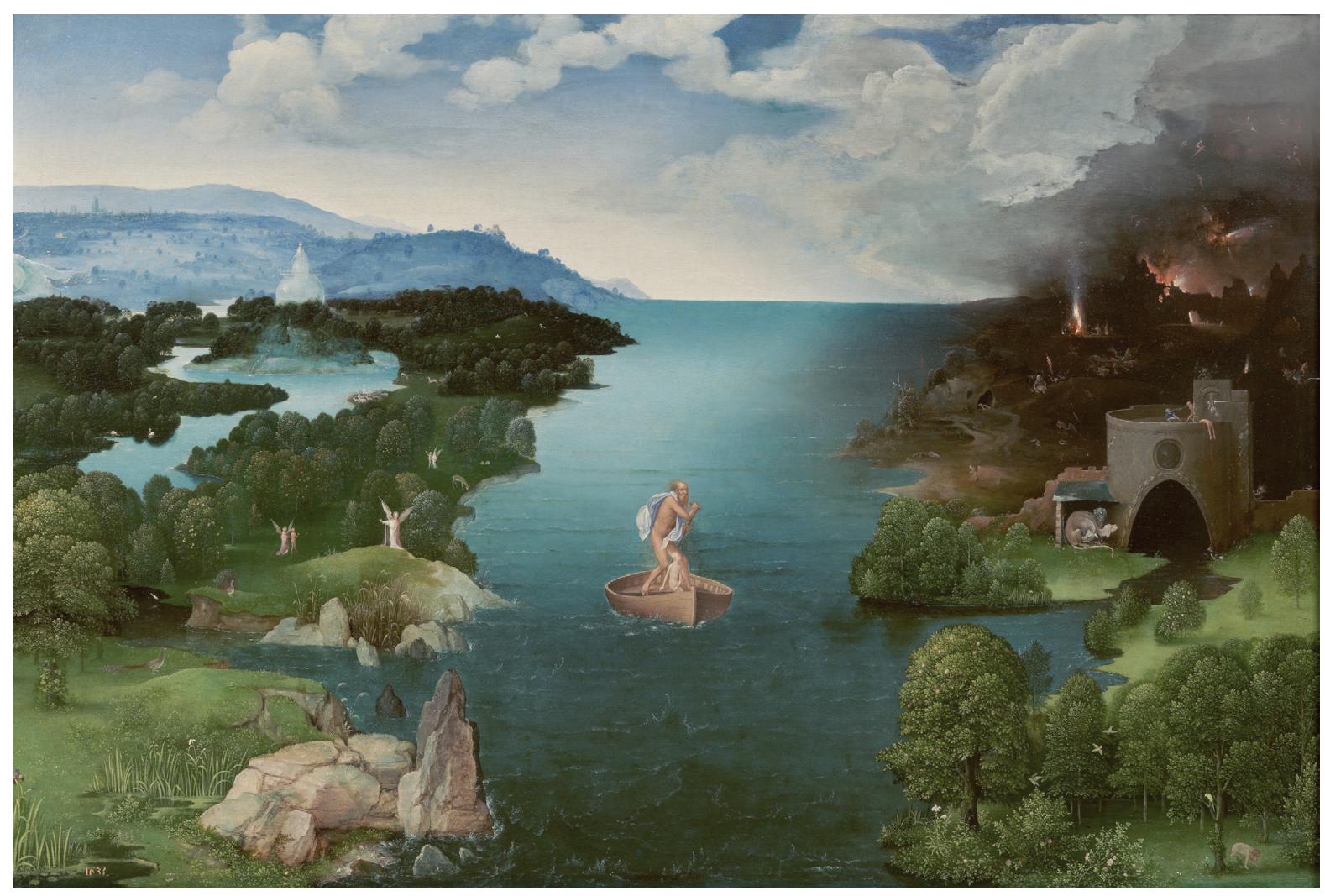

Kuva 1. Joachim Patinir, Kharon ylittämässä Styks-jokea, n. 1520-1524. Öljyväri puulle, 64 x $103 \mathrm{~cm}$. Prado, Madrid. Kuva: Wikimedia. https://en.wikipedia.org/wiki/Landscape_with_

Charon_Crossing_the_Styx\#/media/File:Crossing_the_River_Styx.jpg (haettu 7.6.2018).

Tarkastelen seuraavaksi tarkemmin Kharon ylittämässä Styks-jokea -maalauksen ikonografiaa. Tavoitteeni on näyttää lukijalle, kuinka se kytkeytyy yhtäältä Cosgroven tunnistamaan utooppiseen kolonialismiin ja toisaalta Ala-Maunuksen maalauksiin. Patinirin näkemyksen kontekstina voidaan nähdä Antwerpenista käsin jo 1400-luvulta lähtien harjoitettu imperialistinen politiikka. Thomas More viittaa Utopiassaan (1516) Antwerpenin kaupunkiin esimerkkinä imperialistisesta kaupankäynnistä. ${ }^{6}$ Patinirin maalaus on myös syntynyt aikana, jolloin Moren Utopia julkaistiin, ja sen voi ajatella havainnollistavan näin myös löytöretkien aikakauden kristilliseen paratiisikäsitykseen kytkeytyvää utooppisen maailmanmaiseman käsitettä.

Kharon ylittämässä Styks-jokea -maalaus esittää kohtauksen kreikkalaisesta mytologiasta: alamaailman lautturi Kharon kuljettaa langennutta sielua veneessään Styks-joella kohti kuvitteellista Manalaa. Kristillisesti tulkiten vasemmalla puolella joen uomaa näkyy paratiisi ja oikealla helvetti. Vasemmanpuoleinen manner viittaa ikonografiallaan kristinuskon kertomukseen Eedenin puutarhasta sekä Arkadian myyttiin, johon Styks-joen on katsottu myös johtavan. Paratiisiin ${ }^{7}$ viittaavia elementtejä maalauksessa ovat vehreä laakso, Eedenin lähteen vettä pulppuava korkea torni, enkelit johdattamassa sieluja, hedelmäpuut, etualan kukat (jotka ovat mahdollisesti tulokaslajeja eteläiseltä pallonpuoliskolta), etäiset siniset rinteet ja siellä sijaitseva kaupunki (mahdollisesti taivaalli- 
nen Jerusalem tai ikuinen Rooma) sekä riikinkukot. Arkadian kuvatyypille ominainen välimerellinen valo on myös läsnä maalauksessa merimaisemalle tyypillisenä, veden ja kirkkaan taivaan muodostamana horisontaalisena pintana. Taidehistorioitsija Harry B. Wehle yhdistääkin vuoristojen sinertävän etäisyyden Patinirin maalauksissa venetsialaiseen maalaustyyliin, jota esimerkiksi Tizianin usein Alppeja kuvaavat maalaukset edustavat. $^{8}$

Nähdäkseni Kharon ylittämässä Styks-jokea heijastaa myös symbolisesti löytöretkien purjehduksia ja viittaa siten utopiakirjallisuuden keskeiseen trooppiin, matkaan. Esimerkiksi paratiisin hedelmälehdossa tepastelevat, väritykseltään riikinkukkoa muistuttavat linnut viittaavat Intiaan, josta laji on kotoisin. Eurooppalaiset löytöretkeilijät, ja hellenismin kaudella esimerkiksi Aleksanteri Suuri, toivat lajin Eurooppaan. Riikinkukosta kirjoitettiin esimerkiksi espanjalaisten löytöretkien aikana 1500-luvulla. ${ }^{9}$

Patinir on luultavasti nähnyt riikinkukkoja matkoillaan Italiaan, jonne niitä tuotiin Välimeren kauppasatamien kautta. Lisäksi Helvetin sisäänkäynnin edustalla virtaavan joen toisella puolella kulkeva apina ja etualan puiston oksille liitelevät papukaijat viittaavat myös Rooman imperiumin ja löytöretkien aikana valloitettuihin eteläisiin mantereisiin ja sieltä tuotuihin lajeihin. Eksoottisella eläinikonografialla on mahdollisesti yhteyksiä kertomuksiin, joita Patinir on saattanut kuulla venetsialaisen Marco Polon (1254-1324) Itä-Aasian ja Kiinan matkoista. ${ }^{10}$

Katson, että Patinirin maisemaa luettaessa on huomioitava aikakauden imperialistinen konteksti. Patinir teki luonnostelumatkoja eteläiseen Italiaan ja todennäköisesti näki Välimeren rannikon kauppasatamissa kolonialismin konkreettisia tuotteita. Hän mahdollisesti tutustui italialaisten kosmografioihin sekä eurooppalaisten toteuttamiin utooppisiin projekteihin Etelä-Amerikassa, jotka näkyivät esimerkiksi venetsialaisen aateliston omistamien loggioiden eksoottisessa puutarhaestetiikassa. ${ }^{11}$

On erittäin todennäköistä, että Patinirin maalauksen imperialistinen maailmanmaisema sai vaikutteita 1500-luvun löytöretkien maita haltuun ottavasta perspektiivistä. Kharon ylittämässä Styks-jokea on ajoitettu aikavälille 1515/20-1524. Ajanjaksolla löytöretket yleistyivät. Espanjalaiset lähtivät portugalilaisen Fernão de Magalhãesin johdolla purjehdukselle maailman ympäri vuonna 1519. Patinirin synnyinmaasta Flanderista tuli vuonna 1519 osa Espanjaa. Pyhän saksalais-roomalaisen keisarikunnan hallitsijana vuosina 1519-1556 ja Espanjan kuninkaana vuosina 1516-1556 toiminut flaamilaissyntyinen Kaarle $\mathrm{V}$ tuki Espanjan valloituksia Tyynellämerellä, Filippiineillä, Perussa ja Meksikossa. Samaan aikaan Etelä-Amerikkaa valloittanut Kolumbus kuvaili mannerta maanpäällisenä paratiisina. Cosgroven mukaan Kolumbuksen aloittaman kullanhimoisen kolonialismin imperialistinen ja utooppinen perspektiivi vaikutti myös aikakauden maisemakäsityksiin, esimerkiksi Giorgionen (noin 1477 - noin 1510) Jacopo Sannazaron Arkadia-runoelmaa visualisoineisiin maalauksiin, joista Patinir on mitä ilmeisimmin ollut tietoinen. Yhdessä muiden venetsialaisten maalareiden, kuten Tizianin, kanssa Giorgione antoi esimerkiksi valon ja atmosfäärin kuvauksillaan Sannazaron arkadiselle topokselle ja moduksille visuaalisen tulkinnan. Venetsialaiset taidemaalarit vaikuttivat siten keskeisesti eurooppalaisen maisemamaalauksen lajin kehittymiseen, niin kuin myös Hudson-joen koulukunnan maalauksiin. ${ }^{12}$ 
Patinir kuvaa Kharon ylittämässä Styks-jokea -maalauksessaan myös flaamilaisen synnyinkaupunkinsa Dinantin jyrkkiä rantakallioita. Maalauksessa Patinir on sijoittanut ne paratiisin puolelle. Kalliosaarekkeen sekä etäisillä kukkuloilla sijaitsevan kaupungin voi tulkita viittaavan Utopian topografiaan, sillä Moren kertomuksessa Utopia on paratiisin kaltainen inmisen rakentama saareke, jonka pääkaupunki sijaitsee korkealla kukkulalla, kuten eurooppalaiset kaupungit ovat usein sijainneet. ${ }^{13}$

Vuori kuuluu olennaisesti kosmografiaan viittaavaan maailmanmaisemaan. Taidehistorioitsija Simon Schama tunnistaa Patinirin kuva-aiheissa myös Eedenin vuoren ikonografian piirteitä, kuten Eedenin lähteen korkean tornin, erillisiä saarekemaisia vuoria, jyrkkiä rantakallioita ja paratiisin laakson. Schaman mukaan pyhimyslegendoihin kytkeytyvien vuoristomaisemien ja Eedenin vuoren ikonografian yksi edeltäjä on 1100-luvulla kirjoitettu teos Descriptio, joka kuvaa matkaa Siinainvuoren Pyhän Katariinan luostariin. Eedenin vuoren sijainnista on erilaisia tulkintoja. Esimerkiksi Patinirin maalausten Kharon ylittämässä Styks-jokea ja Pyhä Hieronymus erämaassa (n. 1515-1520, öljy le- vylle, 78 x $137 \mathrm{~cm}$, Louvre, Pariisi) vuoriston, paratiisilaakson ja tornien kuvaukset lukeutuvat Schaman mukaan Eedenin vuoren ikonografiaan. Katson, että Kharon ylittämässä Styks-jokea -maalauksen taustalla siintävät sinertävät kukkulat, paratiisin Eedenin lähteen korkea torni sekä ikään kuin vuorelta käsin havaittu lintuperspektiivi kytkeytyvät tähän Schaman kuvaamaan myyttiin Eedenistä, johon liittyy ajatus nousemisesta vuorelle. Tämä kristillinen humanismi näkyy myös Leonardo da Vincin mielikuvituksellisissa vuoristopiirustuksissa, kuten Myrskyisässä alppimaisemassa (n. 1500). ${ }^{14}$

Katson, että utopian ajatus toistuu taidehistoriassa ideologisena ja metaforisena ${ }^{15}$ maisemaobjektina. Cosgroven maiseman idean määritelmää mukaillen ymmärrän jälkimmäisellä ideaalisia paikkoja, kuten Arkadiaa tai visioita kolonisoidusta eteläisestä mantereesta, kuvaavan länsimaisen maisemamaalaustaiteen. Cosgroven mukaan maiseman idea on esiintynyt historiassa usein esineellistetysti. Ennen teollistumista maiseman ideaa kuvattiin taiteellisesti perspektiivin ja pastoraalitopoksen keinoin maahan kohdistuvana, usein moraalisesti sävyttyneenä tunteena. Porvarillisen kapitalismin yleisty- misen jälkeen maiseman ideasta tuli taas ensisijaisesti tieteellisesti määritelty tutkimuskohde tai subjektin yksilöllisyyden ilmaisemisen muoto. Maiseman ideaa ilmaistiin myös esineellistetyn maaston hyötyarvona. Tieteellinen perspektiivi, kuten teknologinen kehitys, vaikutti edellisiin, erityisesti teollisen kapitalismin aikaisiin, maiseman ideoihin ja niissä näkyvään kolonialismiin sekä utopia-ajatteluun. ${ }^{16}$

Maisemaobjektit eli länsimaisen taiteen historiaan lukeutuvat maisemamaalaukset sisältävät usein idealisoituun utooppiseen paikkaan kohdistuvan kolonialistisen perspektiivin. Thomas Moren (1516) tunnetuksi tekemä utopian käsite, jota pohjustavat kreikan kielen termit eu-topos ja ou-topos, tarkoittaa paratiisin kaltaista kuvitteellista hyvää paikkaa. Utopioille on ominaista kytkeytyminen poliittiseen ja yhteiskunnalliseen ajatteluun. Paratiisit ovat inmistä suurempien olentojen aikaansaannoksia, kun taas utopiat ovat inmisten poliittisella ja yhteiskunnallisella toiminnallaan luomia parempia yhteiskuntia, kuten politiikan tutkija Lyman Tower Sargent toteaa. Utopiat ovat kuitenkin saaneet visuaalisen ikonografiansa paratiisikertomuksista, kuten Arkadiasta ja Eedenin 
VTOPIAE INSVLAE FIGVRA

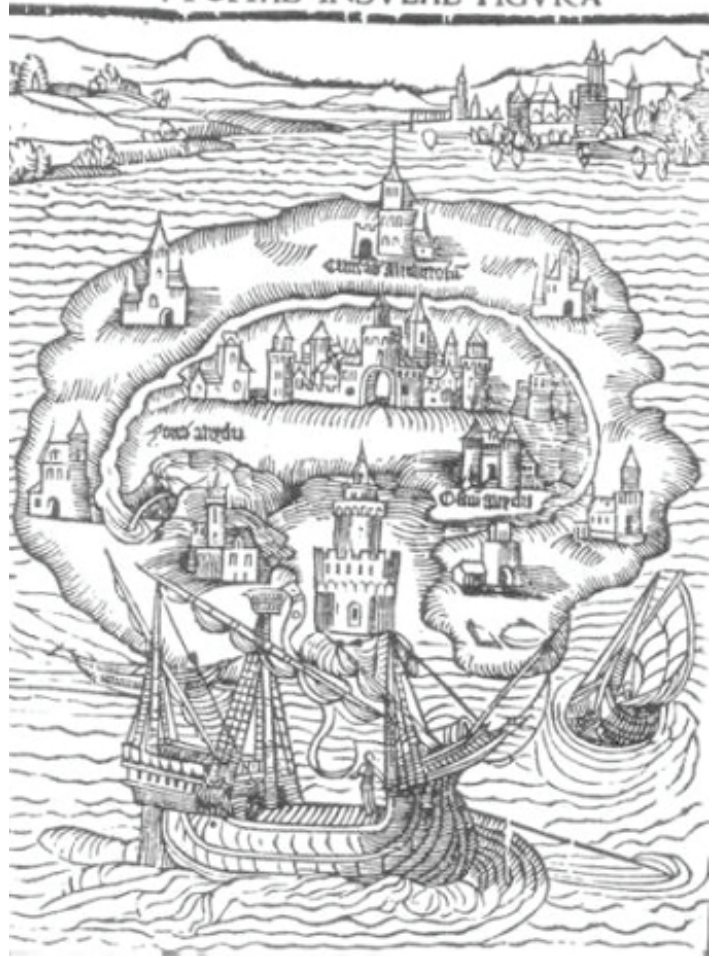

Kuva 2. Ambrosius Holbein, Thomas Moren Utopian 1. painoksen (1516) kuvitus, 1516. Puupiirros. Kuva: Wikimedia Commons. https://en.wikipedia.org/wiki/Utopia_(book)\#/medial File:Isola_di_Utopia_Moro.jpg..... (haettu 7.6.2018). puutarhasta. ${ }^{17}$

Ajattelen, että maiseman käsite ja maisemamaalaus ovat olennainen osa utopioiden historiaa. Jo Ambrosius Holbeinin tekemä Thomas Moren Utopian kuvituskuva (1516) esittää kukkulaisen rannikkomaiseman Utopian saaren taustalla. Utopiassa maisema on myös olennainen osa kuvattua ihannekaupunkia sekä yhteiskuntaa ja piirtyy esiin esimerkiksi Moren kuvailemilla puutarhan, rannikon ja joen maisemaelementeillä. ${ }^{18}$

\section{Ikonografis-aatehistoriallinen lähestymistapa}

Useampia maisema-aiheisia näyttelyitä 2010-luvulla pitänyt Petri Ala-Maunus (s. 1970) katsoo öljyvärimaalaustensa kuvaavan "utooppista maisemaa". ${ }^{19}$ Tarkastelen seuraavaksi Ala-Maunuksen maalauksissaan La-la Land (2012) ja Übernatur (2012) apokalyptis-utooppisina toteuttamia paratiisin ja maailmanmaiseman (Weltlandschaft) topoksia. Artikkelin primääriaineistoksi valitsin yllä mainitut maalaukset, koska ne edustavat hyvin Ala-Maunuksen 2000-luvun tuotannossa toistuvaa utooppista, paratiisiin ja maailmanmaisemaan apokalyptissävyisesti viittaavaa vuoristo- ja laaksomaisematyyp- piä. Tarkoitan topoksella ${ }^{20}$ taidehistoriassa ja ikonografiassa tunnistettua, taiteessa toistuvaa maisemakuva-aihetta ja -tyyppiä ${ }^{21}$ sekä myös paikkaa, johon se viittaa, kuten esimerkiksi maaseutupastoraalin tai pittoreskin vuoristomaiseman tapauksessa.

Tavoitteeni on kontekstualisoida aate- ja taidehistoriallisesti Ala-Maunuksen maisemamaalausten varioimaa utopian ikonografiaa, jossa tulkitsen 2000-luvun "satelliittiperspektiivin" yhdistyvän 1500-luvun kolonialistiseen maailmanmaisemaan. Määritän yhdeksi Ala-Maunuksen maalausten La-la Land ja Übernatur utooppiseksi topokseksi avaran maailmanmaiseman, jossa käsitys universumista tiivistyy yhtenäistettyyn kuvaan.

Tulkitsen Ala-Maunuksen maalauksia ikonografis-aatehistoriallisesti. Analysoin maalausten ikonografiaa, kuten maisemaelementtejä. Kontekstualisoin artikkelissa Ala-Maunuksen maalausten 2000-luvun maailmanmaiseman utooppisen kolonialismin ja kapitalismin aatehistoriaan. Käytännössä vertailen Ala-Maunuksen maalausten La-la Land (2012) ja Übernatur (2012) maailmanmaiseman ja paratiisin ikonografiaa samoihin topoksiin kuin yllä olevassa ana- 
Iyysissani Joachim Patinirin (n. 1480-1524) maalauksesta Kharon ylittämässä Styks-jokea (n. 1520-1524).

Nähdäkseni Ala-Maunuksen maailmanmaisemat ovat luettavissa semiootikko Eero Tarastin maiseman käsitettä tulkitsevan "elementaaristruktuuri[n]" avulla. Strukturaalisessa kuva-analyysissään Tarasti jaottelee maiseman merkityksen yhtäältä positiiviseen tai negatiiviseen ja toisaalta kulttuurin sisäiseen tai ulkoiseen. ${ }^{22}$ Katson tämän mallin soveltuvan hyvin Ala-Maunuksen maailmanmaiseman tulkintaan, tosin niin, että kahtiajaot ylittyvät. Maalauksissa utooppinen maisema on merkitykseltään sekä positiivinen että negatiivinen, toisin sanoen dystooppis-utooppinen tai apokalyptis-utooppinen eli fantasiakirjailijaa China Miévilleä lainaten apokatopinen. Lisäksi kuvattu maisema viittaa osittain pohjoiseen ilmastoon ja maantieteeseen, vaikka kuvaakin pääasiassa eteläistä ilmastoa ja maisemaelementtejä.

\section{Apokatopia}

Ala-Maunuksen myöhäisemmässäkin maalaustuotannossa, esimerkiksi vuodelta $2018^{23}$, kansallisen kulttuurin sisäistä positiota kontrastoi globaali kulttuurille ulkoi- nen maailmanmaisema. Tulkitsen, että viime vuosien ilmastoraportit saattavat näkyä Ala-Maunuksen vuoden 2018 maisemamaalauksissa, joissa eteläinen ja pohjoinen ilmasto fuusioituvat.

Kuten China Miéville toteaa, apokalypsi liittyy utopioiden historiaan, tuhon kautta tapahtuvan paratiisin tulemisen sekä "uuden alun" kertomuksina. Hän katsoo, että 2010-luvulla dystopian on korvannut apokatopia ("apocatopia" ja "utopalypse"), kun haaveiden ja painajaisten kuvat ovat sekoittuneet. Jälkimmäisellä Miéville tarkoittaa luennassani mediassa päivittäin esillä olevia tuhon näkymiä sekä 2000-luvun TV- ja elokuvateollisuudessa toistuvaa apokalyptistä maisemakuvastoa, jollaisia nähtiin esimerkiksi tanskalaisessa The Rain-televisiosarjassa (2018). Hän näkee syyn muutokselle nykyisessä mediakulttuurissa, jossa korostetaan tuhoa ja turmiota sekä unelmia maailmasta, jossa ei ole inmisiä ja jota ainoastaan eläimet tutkivat, toisin sanoen kuvastoa, jota esimerkiksi television luontodokumentit ja uutismedia välittävät. Katastrofien ja tuhon kuvat voidaan nähdä myös kauniina ja katsojalle osana normaalia päivittäistä kuvastoa. Esimerkkinä apokatopiasta Miéville mainit- see maailman tuhoisimmaksi teollisuusonnettomuudeksi arvioidun Union Carbide -tehtaan kaasuvuodon Intian Bhopalissa. Vastuuttoman talousutopian tavoitteleminen kustannettiin tuhansien inmisten kuolemilla, vammautumisilla sekä paikallisen ympäristön ja pohjaveden myrkyttymisellä. ${ }^{24}$

Apokalyptinen ajattelu on myös esillä taidehistoriassa. Filosofi Ivan Boldyrev tunnistaa ajatuksen filosofi Ernst Blochin (1885-1977) kirjoituksiin vaikuttaneessa ekspressionistisessa taiteessa. Taidehistorioitsija Robert Rosenblum katsoo apokalypsin olevan keskeinen teema 1800-luvun romantiikan maisemamaalauksen lisäksi modernissa 1900-luvun taiteessa. ${ }^{25}$ Ala-Maunuksen maalauksissa La-la Land ja Übernatur on havaittavissa modernin utopia-ajattelijan Ernst Blochin erottelemat kaksi utopian tyyppiä: yhtäältä maailman rajamailla esiintyvät pohjoinen myrsky ja usva sekä toisaalta eteläinen keskikesä. ${ }^{26}$ Nämä Blochin määrittämät kaksi utopian tyyppiä ovat myös yhteyksissä China Miévillen apokatopian käsitteeseen. La-la Land ja Übernatur -maalauksista löytyvät molemmat, sekä eteläinen Arkadia että talvisen usvainen apokalypsi. Taivaanrajaa hipovat korkeat lumiset vuorenhuiput ja 
Eedenin lähteisiin viittaavat vesiputoukset muistuttavat Kharon ylittämässä Styks-jokea -maalauksen ikonografiaa. Ala-Maunus on kuitenkin lisännyt näkymään apokalyptisen sävyn ukkosmyrskyä enteilevälle taivaalle, mikä on samankaltainen kuin Patinirin maalauksessa. Apokatopinen jännite saa katsojan pohtimaan, kenen näkökulmasta paratiisimaisen vuoristolaakson näkymää esitetään.

Katson, että yhtenä Ala-Maunuksen maalausten keskeisenä temaattisena ulottuvuutena ovatkin maisemamaalauksen kulttuuriset merkitykset 2000-luvulla. Paratiisimaiseman vuoristo- ja laaksoelementit ovat kuluneita kuva-aiheita (esimerkiksi pitserian seinän koristeina) ja replikoituja uskonnollisen vakaumuksen symboleita (esimerkiksi Jehovan todistajien Vartiotorni-lehden paratiisimaisemassa). ${ }^{28}$ Ala-Maunus kyseenalaistaa maalaustensa apokatopisella moduksella maailmanmaisemille tyypillisen, kuluneen, ylevän vuoristonäkymän, josta on filosofi Tomáš Kulkan mukaan tullut kitschiä modernin massakulttuurin jäljiltä. ${ }^{29}$ Myös vuoristokuvaston tulva internetissä viittaa 2000-luvun digikansalaisen maailmankuvaan, johon sisältyy maailmanmaiseman tavoin koko uni-
Kuva 4. Petri Ala-Maunus, La-la Land, 2012. Öljyväri kankaalle, 170 × $170 \mathrm{~cm}$. Kuva: Galleria Sculptor.

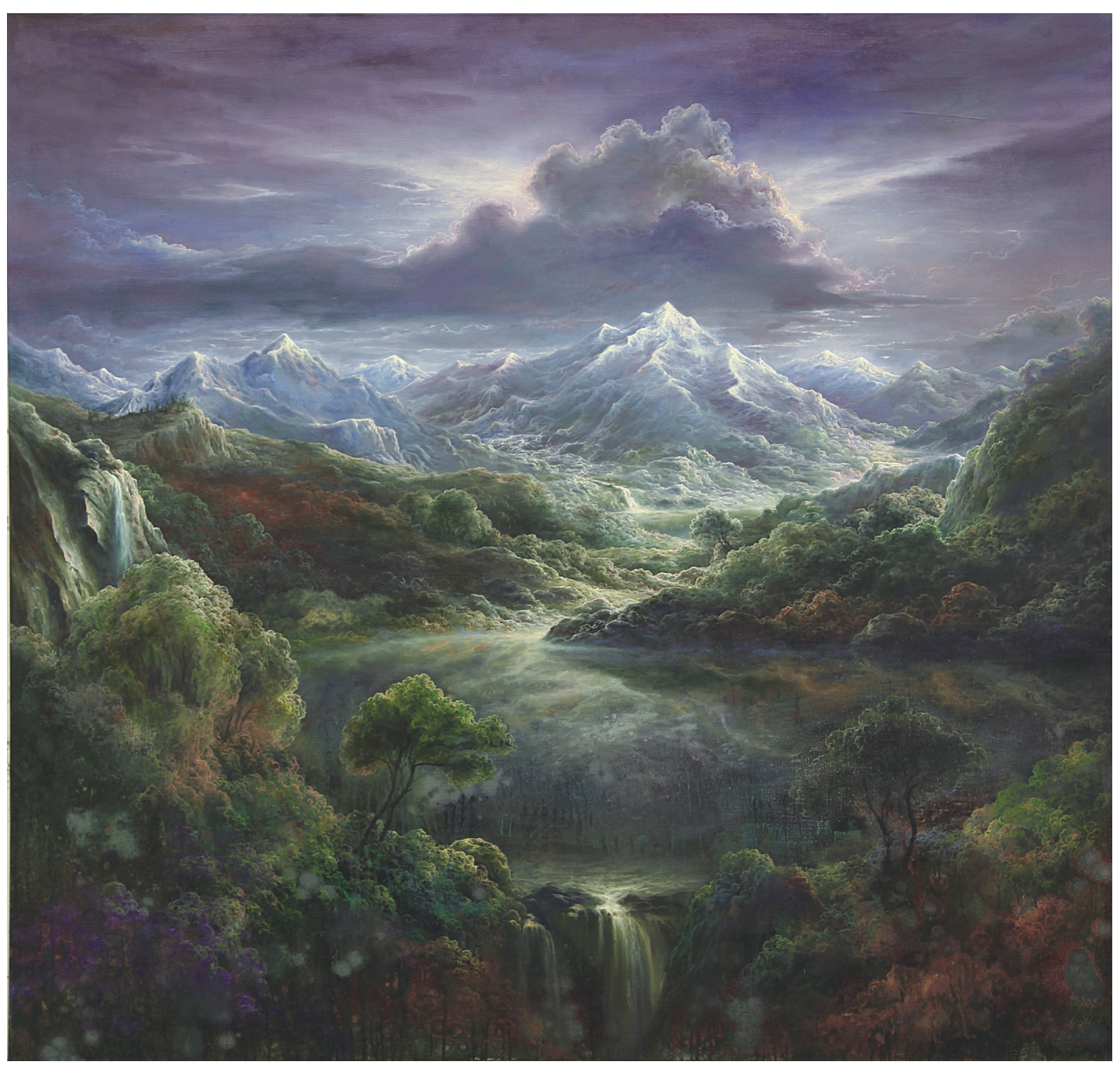


versumia havainnoiva ja hallinnoiva perspektiivi.

Vuonna 2018 ilmaperspektiivikuvat ovat taiteen tavoin tuotettuja ja ostettavia maisemanäkymiä, joilla on yhteiskunnallinen funktio. Esimerkiksi Google Mapsin ${ }^{30}$ kanssa työskentelevän Planet-yhtiön tavoitteena on kuvata koko maapallon pinta kaikkien tavoitettavaksi dataksi. Maapallomme tila on valvonnassa. Yhtiö myy satelliittikuvadataa, mutta tarjoaa sitä myös ilmaiseksi mm. hyväntekeväisyysjärjestöille ja tutkijoille. Esimerkiksi maatalousyhtiöt pystyvät satelliittikuvien avulla ajoittamaan lannoittamisen, ja metsäkatoja pystytään torjumaan. ${ }^{31}$ Datan hallinta sisältää kuitenkin mahdollisuuden taloudelliseen hyötykäyttöön ja sen ylilyönteihin.

Ala-Maunuksen tapa varioida utooppisia paratiisin ja maailmanmaisemia kyseenalaistaa sekä internetin kuvastoon liittyvän suuryhtiöiden harjoittaman datakapitalismin että maisemamaalauksen historiassa toistuvan imperialistisen perspektiivin. Ala-Maunus paljastaa internetissä googlaamalla havaittavan maailmanmaiseman apokatopisuuden.

Vuonna 2017 varakkain prosentti $(0.7 \%)$ maailman ihmisistä omistaa noin puolet (46
\%) maailman rikkauksista. Imperialistisesta perspektiivistä nähty 2000-luvun maailmanmaisema kuuluu vain harvoille. Google Maps -ohjelma mahdollistaa ainoastaan kuvitteellisen maailmanmaiseman haltuunoton. Ohjelman kartta- ja maisemadata ovat vain näennäisesti demokraattisia, sillä datan omistaa ja tuottaa monopoliyhtiö Google. Lisäksi yksittäinen inminen ei ainakaan vielä toistaiseksi kykene esineiden internetissä, kuten mobiiliverkkoon kytketyillä älypuhelimilla, televisioilla ja tietokoneilla, kontrolloimaan tuottamaansa käyttäjädataa, kuten paikkatietoja. Tähän datakapitalismiin lohkoketjuteknologia etsii parhaillaan ratkaisuja. ${ }^{32}$

Teollinen maatalous, haitalliset vieraslajit ja kuivuvat joet ovat 2000-luvulla todellisuutta, joka tuottaa oman merkitystasonsa Ala-Maunuksen apokatopisiin maisemiin. Maailmanmaiseman kauneutta rakastava esteettinen kontemplaatio kohtaa hänen maalauksissaan tuhoutuvan maan Patinirin 1500-luvun Kharonin tavoin.

\section{Viitteet}

1 Haluan vielä kiittää vertaisarvioijia käsikirjoituksen huolellisesta kommentoinnista. Kiitän myös Turun yliopiston taidehistorian oppiaineen henkilökuntaa rakentavista keskusteluista, jotka ovat tukeneet artikkelin työstämistä.
2 Denis E. Cosgrove, Social Formation and Symbolic Landscape (Wisconsin: The University of Wisconsin Press, 1998), xix, 165 ja Denis Cosgrove "Landscape and Global Vision", teoksessa Sites Unseen. Landscape and Vision, ed. Dianne Harris \& D. Fairchild Ruggles (University of Pittsburgh Press, 2007).

3 Ks. esim. Craig Harbison, The Art of the Northern Renaissance (Weidenfeld \& Nicolson, 1995), 139 ja Susan H. Jenson, "Patinir...", teoksessa Renaissance and Reformation, 1500-1620: A Biographical Dictionary, ed. Jo Eldridge Carney (London: Greenwood Publishing Group, 2001), 280.

4 Simon Schama, Landscape and Memory (London: Fontana Press, 1996), 431.

5 Cosgrove, "Landscape and Global Vision", 92-93. 6 Thomas More, "Utopia”, teoksessa Ligeia Gallagher (ed.), More's Utopia and Its Critics (Chicago: Scott, Foresman and Company, 1964), 1-68.

7 Paratiisi sana tarkoittaa puutarhaa, joka on ympäröity muurilla. Sana on periytynyt kreikan ja latinan kieliin muinaisen Iranin kirjakielisestä termistä "paridaeza" ("pari”, ympäri; "daeza”, muuri). Termi on usein viitannut kuninkaiden aidattuun metsästyspuistoon. Sana viittaa eurooppalaisessa historiassa usein myös meren takana olevaan eteläiseen vehreään maahan. Kreikan kielelle käännetyn hebreankielisen Raamatun myötä (300 eaa.) paratiisia on alettu Euroopassa käyttää synonyyminä Eedenin puutarhalle. Termi on maailmanlaajuisesti ymmärretty unelmana puhtaasta ja suojatusta onnesta. Helga Ramsey-Kurz \& Geetha Ganapathy-Doré (ed.), Projections of Paradise: Ideal Elsewheres in Postcolonial Migrant Literature (New York: Rodopi, 2011): viii-xvii.

8 Ks. esim. "Charon", luettu 30.7.2018, https:!!! www. britannica.com/topic/Charon-Greek-mythology; Hesiodos, Jumalten synty (Theogonia), suom. Päivi Myllykoski (Helsinki: Tammi, 2002) ja Harry B. Wehle, "A Triptych by Patinir", The Metropolitan Museum of Art Bulletin 31 (4, Apr.) /1936: 84. 
9 Ks. esim. Wehle, "A Triptych by Patinir", 82; C.H Whitman, "The Birds of Old English literature", The Journal of Germanic Philology, 2 (2) /1898: 40 ja Albert Hazen Wright, "Early Records of the Wild Turkey", The Auk 31 (3, Jul.) /1914: 334-358. Esimerkiksi Gonzalo Fernandez de Oviedo y de Valdes matkusti vuosina 1514-1517 ja 1519-1523 Panaman Darienin alueelle, jonka riikinkukkolajia hän vertaa Espanjassa tavattuun.

10 Ks. esim. H. W. Janson, "The Fettered Ape", Apes and Ape Lore in the Middle Ages and the Renaissance (London: The Warburg Institute, University of London, 1952); M. Masseti \& C. Veracini, "Early European knowledge and trade of Neotropical mammals: a review of literary sources between 1492 and the first two decades of the 16th century", British Archaeological Review 2662/2014: 129-138; "Marco Polo", luettu 21.7.2018, http://wwww.britannica com/EBchecked/topic/468139/Marco-Polo (2010 ja Laurence Bergreen, Marco Polo: From Venice to Xanadu (New York: Knopf Doubleday, 2007). 11 Cosgrove, Social Formation, xix, 164-167. 12 Ks. Harald Kleinschmidt, Charles V: The World Emperor (UK: The History Press, 2011); Eviatar Zerubavel, Terra Cognita: the Mental Discovery of America (New Jersey: Transaction Publishers, 2003), 90-91 ja Cosgrove, Social Formation, 164-166.

Sannazaron Arkadia julkaistiin Venetsiassa vuonna 1502. Teksti kuvaa Vergiliuksen pastoraalimyyttiä, jossa Cosgroven sanoin vehreät niityt ja kultainen auringonvalo symboloivat rakkautta. Myös luonnonvesilähde sisältyy tähän arkadiseen topokseen. Cosgrove lukee Sannazaron Arkadian nostalgisena myyttiseen menneisyyteen haikailevana utopiana, joka jättää huomioitta aikakautensa yhteiskunnallisen todellisuuden. Cosgrove, Social Formation, 122.

13 Ks. Schama, Landscape and Memory, 415-416 ja W. N. A Boerefijn, "The Foundation, Planning And Building Of New Towns In The 13th And 14th Centuries In Europe: An Architectural-Historical
Research Into Urban Form And Its Creation" (PhD diss., University of Amsterdam, 2010), 217.

14 Schaman sanoin vuoren "shamanistista ja askeettista luonnetta" kuvaa erityisesti Pyhä Hieronymus -maalausten erakko. Schaman mukaan Eedenin vuoren kuvatyypin lähtökohtana on Pyhän Hieronymuksen oletetusti kirjoittama teos Liber locorum, joka vaikutti myös Descriptio-teoksen (n. 1100) Eedenin vuoren kuvaukseen. Descriptiossa Eedenin vuori on kuin "korkea torni", ja sieltä näkyy aavikon keskellä oleva vehmas paratiisi kristallinkirkkaan puron äärellä, jossa vallitsee "ikuinen kevät". Tämä kuvaus Eedenin vuoresta on Schaman mukaan kristillisen pyhän vuoren arkkityyppi. Ks. Schama, Landscape and Memory, 415-417, 426. Ks. Eedenin vuoresta myös John Wilkinson, Joyce Hill and W.F. Ryan (ed.), Jerusalem Pilgrimage, 1099-1185 (London: The Hakluyt Society, 1988) ja "Biblical Archaeology: Mt. Sinai", Luettu 30.7.2018, htttps://wwww.bibleands cience.com/ archaeology/mtsinai.htm

15 Ernst Bloch, The Principle of Hope, eds. and tr. N. Plaice, S. Plaice and P. Knight (Cambridge: The MIT Press, 1986).

16 Cosgrove, Social Formation, xix, xxii-xxiii, 64. Ks. myös Mitchell, William J. Thomas 1994. Imperial Landscape. Toim. Mitchell, William J. Thomas.

Landscape and Power. Chicago: University of Chicago Press, 7.

17 Sargent, "Utopian Traditions Themes and Variations", 8-9.

18 More, "Utopia", 1-68.

19 Petri Ala-Maunus, haastattelu (Hilja Roivainen, 18.5.2013, audio 92min)

20 Topos voi merkitä esimerkiksi vakiintuneita tapoja esittää elinympäristöä. Ks. esim. Ernst Robert Curtius, European Literature and the Latin Middle Ages (Princeton: Princeton University Press, 2013), xvii, 242 ja John Hesk, "'Despisers of the Commonplace': Meta-topoi and Para-topoi in Attic Oratory", Rhetorica: A Journal of the History of Rhetoric 25 (4/2007): 362
Termi topos tarkoittaa yleisesti "yhteistä (jaettua) paikkaa" ja tulee kreikankielisestä sanasta "tópos" (monikossa "topoi"), joka tarkoittaa paikkaa tai sijaintia. Kirjallisuudessa ja retoriikassa topos viittaa yleisesti ymmärrettyyn tapaan. Olen määritellyt topoksen käsitettä aikaisemmin artikkelissani: Hilja Roivainen, "Dialektinen utopia. Asger Jornin taide ja Ernst Blochin utopia-ajattelu", Ennen ja nyt: Historian tietosanomat, nro. 2 (2017), luettu 14.1.2019, htttp:!!! www.ennenjanyt.net/2017/08/dialektinen-utopiaasger-jornin-taide-ja-ernst-blochin-utopia-ajattelu/. 21 Altti Kuusamo, Tyylistä tapaan. Semiotiikka, tyyli, ikonografia (Helsinki: Gaudeamus, 1996).

22 Eero Tarasti, "Maiseman semiotiikasta", teoksessa Johdatusta semiotiikkaan: esseitä taiteen ja kulttuurin merkkijärjestelmistä (Helsinki: Gaudeamus, 1990), 157.

23 Ks. esimerkkinä pohjoiseen ilmastoon

viittaavasta kuusikkoisesta ja tummanpuhuvasta maisemasta Ala-Maunuksen maalaus Winterfell (2016-2018, öljy kankaalle, 170 x 200 cm); eteläisen ja pohjoisen ilmaston sekä maaston elementtejä, kuten auringonvaloa, kullan kellertävää sävyä ja kuusikkoista vuoristoa, yhdistelevistä maalauksista Sunny Valley (2017-2018, öljy kankaalle, 110 x $350 \mathrm{~cm}$ ), Moon River (2017-2018, öljy ja akryyli kankaalle, 150 x $150 \mathrm{~cm}$ ) ja Neue Welt (2017-2018, öljy kankaalle, $200 \times 450 \mathrm{~cm}$ ). Maalaukset olivat esillä Ala-Maunuksen yksityisnäyttelyssä "The New Wild" Turun Makasiini Contemporaryssä 3.3.-15.4.2018. 24 China Miéville, "The Limits of Utopia", teoksessa Utopia by Thomas More, ed. David Price 1901 (London: Verso, 2016), 20-23 ja Sargent, "Utopian Traditions Themes and Variations", 8-9. Sargent yhdistää utopioihin myös apokalypsikertomuksen. Ks. myös "Union Carbide/Dow lawsuit (re Bhopal)", luettu 27.7.2018, https:///www.bussiness-humanrights.org/en/ union-carbidedow-lawsuit-re-bhopal.

25 Ivan Boldyrev, Ernst Bloch and His

Contemporaries: Locating Utopian Messianism

(London: Bloomsbury Publishing, 2014), 98 ja Robert 
Rosenblum, Modern Painting and the Northern Romantic Tradition. Friedrich to Rothko (London: Thames \& Hudson, 1975), 142, 146.

26 Bloch, The Principle of Hope, 781. Bloch määrittää äärimmäisen pohjoisen, Ultima Thulen, utopian elementeiksi pohjoisen ilmaston, myrskyisen yön, sumun ja keskitalven juhlan eli joulun. "[...] to the north a magic of death utopianizes itself geographically, which contains within it a complete destruction of the world, but also seeks to overcome it, with a paradoxical homeland." Thulen vastakohta on raamatullinen kolonisoitu, linnamainen etelän utopia.

27 Cosgrove, "Landscape and Global Vision", 93. 28 Ala-Maunus, haastattelu.

29 Tomáš Kulka, Taide ja kitsch, suom. Eero Balk (Helsinki: Taifuuni, 1997), 24

30 Kalifornian laakson Mountain View'ssä päämajaa pitävä Google lanseerasi vuonna 2005 Google Maps -ohjelman. Ohjelman avulla globaalin maiseman katseleminen on 2000-luvulla demokratisoitunut. Google Earth -ohjelma puolestaan tuottaa geokuvastoa 2D-satelliittikuvien sekä 360-asteisten lentokone- ja autokameroiden avulla. Kuvasto on koottu yhteen fotogrammetrialla mallintaen. Ohjelma mahdollistaa "demokraattisen" löytöretkeilyn maapallolla, virtuaalimaailmassa. Kansallispuistojenkin vuoret ovat katseltavissa ohjelman avulla. Jälkimmäisen ohjelman "Pretty Earth" -kuvastossa puolestaan on esimerkiksi aina kevät - utooppisen lyydisesti. Ks. esim. "Founders' IPO Letter From the S-1 Registration Statement, 2004", luettu 20.7.2018, https://wwww.google.co.uk! about/our-companyl!; "Google Company: Our history in depth", luettu 20.7.2018, https://www.scribd. com/document/334801840/Our-History-in-DepthCompany-Google ja "Google Earth's "Google Earth's Incredible 3D Imagery, Explained”, luettu 20.7.2018, https://www.youtube.com/watch?v=suo aUTUpps\# ga $=2.222015633 .805123207 .1532969404-$ 814493860.1532969404
31 "Planet", luettu 20.7.2018, https://www.planet. com/ ja "Satelliittien ennätysmies Will Marshall: "Sitkeys erottaa menestyvät yrittäjät niistä, jotka eivät menesty"', luettu 23.7.2018, https://yle.fi/ untisset/3-9956373.

32 Ks. esim. "Richest 1\% own half the world's wealth, study finds", luettu 21.7.2018, https://www. theguardian com/inequality/2017/nov/14/worldsrichest-wealth-credit-suissse. Ks. myös Anthony Shorrocks, Jim Davies ja Rodrigo Lluberas,

"Global Wealth Report 2017" (Credit Suisse Group AG: Credit Suisse Research Institute, 2017), 21, luettu 21.7.2018, https://www.credit-suisse.com/ corporate/en/research/research-institute/globalwealth-report.htm!; "Internet of things selkokielellä" luettu 21.7.2018, htțps://blogit.haaga-helia.fi! ryynanen/2016/02/29/mita-internet-of-things-voitarkoittaa-selkokielella/. ja "Yle Kryptolaaksossa: Esineiden internetissä jääkaappisikin tuottaa arvokasta tietoa - Tulevaisuudessa voit myydä laitteidesi tuottaman datan", luettu 21.7.2018, https://. yle.fi/untiset/3-10277865

\section{Kirjallisuus}

Ala-Maunus, Petri. Hilja Roivaisen haastattelu. Turku, 18.5.2013. Audio, 92 min.

Bergreen, Laurence. Marco Polo: From Venice to Xanadu. New York: Knopf Doubleday, 2007. Bloch, Ernst. The Principle of Hope, eds. and tr. N. Plaice, S. Plaice and P. Knight. Cambridge: The MIT Press, 1986. Alkuteos: Bloch, Ernst. Das Prinzip Hoffnung. Suhrkamp Verlag, Frankfurt am Main, 1959.

Boerefijn, W. N. A. "The Foundation, Planning And Building Of New Towns In The 13th And 14th Centuries In Europe: An Architectural-Historical Research Into Urban Form And Its Creation." PhD diss., University of Amsterdam, 2010.

Boldyrev, Ivan. Ernst Bloch and His Contemporaries: Locating Utopian Messianism. London: Bloomsbury
Publishing, 2014.

Cosgrove, Denis E. Social Formation and Symbolic Landscape. Wisconsin: The University of Wisconsin Press, 1998.

Cosgrove, Denis E. "Landscape and Global Vision". Teoksessa Sites Unseen. Landscape and Vision, ed Dianne Harris \& D. Fairchild Ruggles. Pittsburgh: University of Pittsburgh Press, 2007.

Curtius, Ernst Robert. European Literature and the Latin Middle Ages. Princeton: Princeton University Press, 2013.

Hazen Wright, Albert. "Early Records of the Wild Turkey." The Auk 31 (3, Jul.) /1914: 334-358.

Hesiodos, Jumalten Synty. Alkuteos: Theogonia.

Suom. Päivi Myllykoski. Helsinki: Tammi, 2002.

Hesk, John. 'Despisers of the Commonplace': Metatopoi and Para-topoi in Attic Oratory". Rhetorica: A Journal of the History of Rhetoric 25 (4/2007): 362 Janson, H. W. "The Fettered Ape." Apes and Ape Lore in the Middle Ages and the Renaissance.

London: The Warburg Institute, University of London, 1952.

Jenson, Susan H. "Patinir..." Teoksessa

Renaissance and Reformation, 1500-1620: A

Biographical Dictionary, ed. Jo Eldridge Carney. London: Greenwood Publishing Group, 2001. Kleinschmidt, Harald. Charles V: The World

Emperor. Stroud: The History Press. 2012.

Kulka, Tomáš. Taide ja kitsch. Suom. Eero Balk. Helsinki: Taifuuni, 1997.

Kuusamo, Altti. Tyylistä tapaan. Semiotiikka, tyyli, ikonografia. Helsinki: Gaudeamus, 1996.

Masseti M. \& Veracini C. "Early European knowledge and trade of Neotropical mammals: a review of literary sources between 1492 and the first two decades of the 16th century". British Archaeological Review 2662/2014: 129-138

Miéville, China. "The Limits of Utopia". Teoksessa Utopia by Thomas More, ed. David Price 1901, 11-28. London: Verso, 2016.

Mitchell, William J. Thomas 1994. Imperial 
Landscape. Toim. Mitchell, William J. Thomas. Landscape and Power. Chicago: University of Chicago Press.

More, Thomas. 'Utopia'. Teoksessa More's Utopia and its Critics, ed. Ligeia Gallagher, 1-68. Chicago: Scott, Foresman and Company, 1964.

Ramsey-Kurz, Helga \& Ganapathy-Doré, Geetha (ed.). Projections of Paradise: Ideal Elsewheres in Postcolonial Migrant Literature. New York: Rodopi, 2011.

Roivainen, Hilja. "Dialektinen utopia. Asger Jornin taide ja Ernst Blochin utopia-ajattelu". Ennen ja Nyt: Historian Tietosanomat nro. 2 (2017). Luettu 1.6.2018. http://www.ennenjanyt.net/2017/08/ dialektinen-utopia-asger-jornin-taide-ja-ernst-blochinutopia-ajattelu!l.

Rosenblum, Robert. Modern Painting and the Northern Romantic Tradition. Friedrich to Rothko. London: Thames \& Hudson, 1975.

Sargent, Lyman Tower. "Utopian Traditions: Themes and Variations". Teoksessa Utopia. The Search for the Ideal Society in the Western World, eds. Roland Schaer, Gregory Claeys \& Lyman Tower Sargent, 8-17. New York: New York Public Library, 2000.

Schaer, Roland; Claeys, Gregory \& Sargent, Lyman Tower (eds.). Utopia. The Search for the Ideal Society in the Western World. New York: New York Public

Library, 2000.

Schama, Simon. Landscape and Memory. London: Fontana Press, 1996.

Tarasti, Eero. "Maiseman semiotiikasta". Teoksessa Johdatusta Semiotiikkaan: esseitä taiteen ja kulttuurin merkkijärjestelmistä. Helsinki: Gaudeamus, 1990.

Wehle, Harry B. "A Triptych by Patinir". The

Metropolitan Museum of Art Bulletin 31 (4, Apr.)

11936: 80-84.

Whitman, C.H. "The Birds of Old English literature". The Journal of Germanic Philology 2 (2) /1898: 40.

Wilkinson, John; Hill, Joyce \& Ryan, W.F. (ed.)

Jerusalem Pilgrimage, 1099-1185. London: The Hakluyt Society, 1988.
Zerubavel, Eviatar. Terra Cognita: the Mental Discovery of America. New Jersey: Transaction Publishers, 2003.

MA Hilja Roivainen viimeistelee Turun yliopiston taidehistorian oppiaineessa monografiaväitöskirjaa utooppisesta maisemamaalauksesta. Artikkeli on osa TOP-säätiön, Turun Yliopistosäätiön, Oskar Öflunds Stiftelsen ja Koneen Säätiön rahoittamaa Utooppinen maisema pohjoismaisessa 2000-luvun maalaustaiteessa -väitöskirjaprojektia. 